creased control over employers. Employer subjection to union discipline, with its sanctions of fines, suspensions, or dismissals, may lessen the employer's resistance to union demands both at the bargaining table and in day-to-day grievance adjustment. The ultimate union sanctions against recalcitrant employer-members would be the traditional strike with picketing, also available against non-members. However, courts might be more likely to sustain the legality of picketing against an employer-member, since such picketing might be viewed as enforcement of internal union discipline, rather than a union attempt to control matters traditionally within the employer's discretion. Yet the union objective of increasing control over employers would seem only slightly furthered by employer membership, and the Barbers Union has not shown the increased control to be necessary or socially desirable. There is no economic reason why union control could not be increased, even to the extent that the division of profits between labor and management is worked out within the political structure of a union containing employers and employees, rather than across the bargaining table. But absent a showing of compelling social advantage to the contrary, it would seem that the employer desire to remain separate from the union should be respected; the independence of the small enterpriser has been traditionally set at a high value in our society.

best interests, coupled with the employee's willingness to let that abstraction, the "union," handle his affairs, as it has in the past.

In the shop card cases, employer resistance to union membership may indicate one reason why the courts did not discuss the problem of employer domination; the union in these cases was undoubtedly employee-dominated and would not have attempted to force membership on employers were there a danger of employer domination involved. However, in the future, employers already in the union may attempt to force membership on other employers in order to achieve or maintain employer domination of the union. The nonactive membership offered the employers under the first union amendment may indicate the union's awareness of the danger of employer domination. In the light of the union's readiness to amend the constitution to afford the employers equal rights, it would seem that courts should not, unless the unions are put in a class with seamen, idiots and infants, strike down the union attempt on the ground that such a course of action will be detrimental to the union. However, a concern over the effects on the public of the elimination of one party to the labor-management dichotomy may lead to a reluctance to enforce the union's attempts.

\title{
CONGRESS $v$. THE COURTS: LIMITATIONS ON CONGRESSIONAL INVESTIGATION
}

The desirability of imposing judicial restraints on congressional investigations has been a controversial issue throughout much of American history. ${ }^{1}$

${ }^{1}$ As inquiries have ranged from liberal to conservative in motivation and character, liberals and conservatives have taken turns supporting and condemning congressional investigations. As one group urged intercession by the courts, the other group has argued against judicial intrusion upon legislative activities. Among the articles arguing against 
Two basic, yet divergent, concepts are woven into the pattern of this conflict. One is that Congress requires broad investigatory powers in order properly to fulfill its law-making function; the other, that the Constitution guarantees to individuals freedom from arbitrary and unreasonable governmental interference. This comment will analyze the role of the federal judiciary when a witness's refusal to answer a question propounded by a congressional committee has resulted in a citation and indictment for contempt. ${ }^{2}$ Primary emphasis will be directed toward the policy factors which underlie the disposition of these cases.

judicial intervention were: Landis, Constitutional Limitations on the Congressional Power of Investigation, 40 Harv. L. Rev. 153 (1926); Wigmore, Legislative Power to Compel Testimonial Disclosure, 19 III. L. Rev. 452 (1924); Potts, Power of Legislative Bodies to Punish for Contempt, 74 U. of Pa. L. Rev. 691 (1926); Frankfurter, Hands Off the Investigations, $33 \mathrm{New}$ Republic 329 (May 21, 1927). Among the articles attacking the investigatory power of Congress and urging judicial intervention were: Coudert, Congressional Inquisition v. Individual Liberty, 15 Va. L. Rev. 537 (1929); Loring, Powers of Congressional Investigation Committees, 8 Minn. L. Rev. 595 (1924).

2 The courts may review congressional investigatory practices when they arise under the Federal Contempt Statute. And, since Congress retains the implied common law power to try and punish contumacious witnesses the courts may review such proceedings upon a petition for a writ of habeas corpus. There is no injunctive relief, however, for alleged mistreatment at the hands of the committee.

The contempt power of Congress has had a long and controversial history. The power of Congress to try and punish a private citizen deemed contemptuous was recognized in Anderson v. Dunn, 6 Wheat. (U.S.) 204 (1821), where the Court held it to be an implied common-law power essential to the effective exercise of the express powers of Congress. Until 1857 the procedure employed was to bring the accused individual before the bar of the Senate or the House where he was, in effect, tried. If a finding of guilt resulted, punishment might be imposed, ranging from a mere reprimand, as in the Anderson case, to imprisonment at the hands of the Senate or House Sergeant-at-Arms for the remainder of the session. Consult, e.g., Kilbourn v. Thompson, 103 U.S. 168, 171 (1880). Trials before the bars of the House of Congress were, however, cumbersome and time consuming proceedings. Further, their effectiveness was seriously limited by a ruling in the Anderson case that imprisonment must terminate with the adjournment of that House. But since the Senate is said to be a continuing body it may be that the power of the Senate to punish a witness does not terminate with adjournment. McGrain v. Daugherty, 273 U.S. 135, 180-82 (1927). For these reasons, Congress in 1857 defined contempt as a statutory offense against the United States, thus making it possible to refer a contumacious witness to the Justice Department for prosecution in the federal courts. 11 Stat. 155 (1857). The legislative purpose of this statute was not so much to provide a statutory definition of contempt as to establish a greater and more effective penalty. 34th Cong. 3d Sess., Cong. Globe, pp. 404-13, 427 (1857); Fields v. United States, 164 F.2d 97 (App. D.C., 1947). The constitutionality of the Act of 1857 was upheld in In Re Chapman, 166 U.S. 661 (1897), where the Court held that Congress might properly define the refusal of a private citizen to testify before its committees as a misdemeanor. It was further stated that this statutory offense did not take the place of the common law offense recognized in the Anderson case but merely supplemented it. The present contempt statute, 52 Stat. 942 (1938), 2 U.S.C. $\$ 192$ (1952), is essentially the same as the Act of 1857 and states in part, "Every person who having been summoned as a witness ... to give testimony ... upon any matter under inquiry before . . . any committee of either House of Congress ... . refuses to answer any question pertinent to the question under inquiry, shall be deemed guilty of a misdemeanor." 
It is now clearly established that Congress possesses the power to seek factual information through committee investigations. ${ }^{3}$ The first extensive consideration by the Supreme Court of the investigatory power of Congress occurred in Kilbourn v. Thompson, ${ }^{4}$ in which it was pointed out that the power of investigation was not expressly granted by the Constitution but was rather an implied power inherent in the enumerated powers. The necessity for implying the power has been stated by the Court to arise from the fact that a legislative body cannot legislate wisely or effectively in the absence of information respecting the conditions which the legislation is intended to affect or change; and where the legislative body does not itself possess the requisite information-which not infrequently is true-recourse must be had to others who do possess it. ${ }^{5}$

While this consideration has led the courts repeatedly to emphasize the importance of the congressional power of investigation, it has been recognized that the exercise of the power will, in many situations, infringe upon the

'Watkins v. United States, 77 S.Ct. 1173 (1957) ; United States v. Rumely, 345 U.S. 41 (1953) ; McGrain v. Daugherty, 273 U.S. 135 (1927); Kilbourn v. Thompson, 103 U.S. 168 (1880). In a related field, the Supreme Court has considered the authority of administrative agencies to seek factual information through commission investigations. In the creation of administrative agencies Congress has expressly authorized the use of the power of investigation. E.g., section 12 of the Interstate Commerce Act authorizes the Commission to "require the attendance and testimony of witnesses and the production of all books, papers and tariffs. ..." Since the members of federal commissions are not members of Congress they have no power to punish contumacious witnesses for contempt. Congress resolved the problem by authorizing the commissions to obtain orders from the federal courts compelling obedience to commission orders. The Supreme Court approved this delegation but firmly declared that the federal courts would not automatically issue orders requested by the commissions but could review the commissions' authority to require the particular testimony and grant the order only in proper cases. It was clear not only that Congress could exercise its investigatory powers by its own committees, but also by statutes delegating it to commissions or other executive agencies. Further, the commissions' authority in each case (power of inquiry) was subject to the same constitutional limitations which attend all investigations conducted under the authority of Congress. Interstate Commerce Comm'n v. Brimson, 154 U.S. 447 (1894).

' 103 U.S. 168 (1880). This case arose from an action for a writ of habeas corpus charging the Sergeant-at-Arms and several of the members of the House of Representatives with false imprisonment. Kilbourn refused to testify or to produce documents at an inquiry into the history of a real estate pool in which Jay Cooke \& Co., debtors of the United States, were interested. He was subsequently found guilty of contempt and held prisoner by the House. The Court found that the inquiry was unrelated to any proper congressional function, that the inquiry was solely the concern of the judiciary and that the incarceration of Kilbourn was therefore unlawful.

${ }^{8}$ McGrain v. Daugherty, 273 U.S. 135, 175 (1927). In 1924 the Senate authorized an investigation of alleged maladministration of the Department of Justice and subpoenaed the Attorney General's. brother Mally Daugherty, an Ohio banker, who disregarded the subpoena and was subsequently arrested by the Sergeant-at-Arms of the Senate. Daugherty applied to an Ohio federal court for a writ of habeas corpus. The District Court granted the writ, relying heavily on the decision in the Kilbourn case and drawing the conclusion that the Senate was not acting in a legislative capacity but was usurping judicial functions. Ex parte Daugherty, 299 Fed. 620 (S.D. Ohio, 1924). The Supreme Court on review reversed the decision of the lower court. 
rights of an individual to conduct his affairs free from governmental interference. The Supreme Court has, for example, prevented Congress from exercising its investigatory power as a means of circumventing constitutional limitations upon the compulsion of testimony in judicial proceedings. ${ }^{6}$ In Quinn v. United States ${ }^{7}$ the Fifth Amendment was held to constitute an absolute limitation on questions which would lead a witness to incriminate himself. Other cases have clearly indicated that this privilege is equivalent in scope to that warranted in judicial proceedings. ${ }^{8}$ But since the protection thus attained is purely personal, a witness cannot come within the scope of the Fifth Amendment if any possible incrimination will not reach him as an individual.

In areas where the privilege against self-incrimination is inapplicable, witnesses have urged the recognition of other constitutional privileges. It has been argued that to compel a witness to produce documents or to testify with respect to his private affairs is in effect a search and seizure prohibited by the Fourth Amendment. ${ }^{9} \mathrm{Mr}$. Justice Brandeis' dissent in Olmstead v. United States $^{\mathbf{1 0}}$ has been cited as authority for this proposition:

[E]very unjustifiable intrusion by the Government upon the privacy of the individual, whatever the means employed, must be deemed a violation of the Fourth Amendment. ${ }^{11}$

This statement was rendered, however, in a case where there had been a "physical invasion" of the witness's premises. The recognized historical purpose of the Fourth Amendment was to prevent the use of governmental force to search a man's house, person, papers or effects and not to provide a testimonial privilege. ${ }^{12}$ In a congressional investigation there is no physical invasion

- Consult Taylor, Grand Inquest, c. 7 (1955).

'349 U.S. 155 (1955).

8 The scope of the privilege against self-incrimination applicable to judicial proceedings has been adhered to by the courts in reviewing contempt citations. See, e.g., Emspak v. United States, 349 U.S. 190, 194-201 (1955). The test for determining whether a question would tend to incriminate a witness was announced by the Supreme Court in Hoffman v. United States, 341 U.S. 479, 486-87 (1951). "[I]t need only be evident from the implications of the question, in the setting in which it is asked, that a responsive answer to the question might be dangerous because injurious disclosures could result."

'United States v. Orman, 207 F.2d 148 (C.A. 3d, 1953). Orman was subpoenaed to appear before the Subcommittee of the Senate's Special Committee to Investigate Organized Crime in Interstate Commerce and to produce all his records and income tax returns for the years 1947-1950. He refused to produce the records unless he received a guaranty that the information contained therein would not be made available to the public. Further questions dealing with the witness's business affairs likewise went unanswered. A contempt citation in four counts and conviction followed. The Court of Appeals affirmed judgment of sentence on two of the four counts.

${ }^{10} 277$ U.S. 438, 471 et seq. (1928). $\quad$ 11 Ibid., at 478.

${ }^{12}$ Olmstead v. United States, 277 U.S. 438, 464 (1928) ; consult also, Warren and Brandeis, The Right to Privacy, 4 Harv. L. Rev. 193 (1890). 
of the sanctity of a man's home, only compulsion for the witness himself to produce the requested evidence.

With the present emphasis by congressional investigators on the area of thought and opinion, there have been attempts to bring the right of privacy under the protection of the First Amendment. ${ }^{13}$ It has been urged that there is a privilege to refuse to testify based upon the First Amendment guarantee of freedom of speech. ${ }^{14}$ Several reasons may be advanced as to why this contention has not been accepted by the courts. In Rumely $v$. United States ${ }^{15}$ the Court of Appeals rejected this argument on the ground that the right of privacy, essentially the right to conduct one's affairs with a minimum of governmental interference, is different in character and governed by different considerations from the constitutionally protected freedom of speech. The public policy which supports freedom of speech is that the safety of democratic government lies in open discussion, a policy which is not served by granting individuals the privilege to remain silent. ${ }^{16}$ Another reason for refusing to recognize the privilege is the acknowledged necessity of a power in Congress to obtain information through committee investigations. The acceptance of an unlimited privilege to refuse to testify before a congressional committee would have the effect of denying to that body access to information which may be necessary to the exercise of its legislative function. As recognized by the Court of Appeals in United States v. Orman:17

[I]t must be remembered that 'the right of free speech is not absolute but must yield to national interests justifiably thought to be of larger importance. The same is true of the right to remain silent.'18

The courts have recognized, however, the danger of untrammeled legislative inquiries into the private affairs of a witness. ${ }^{19}$ An individual summoned before a congressional committee may rely for protection against an undue invasion of his privacy upon the requirements that (1) the investigation relate to a purpose which Congress can constitutionally entertain and (2) the

${ }^{13}$ For a discussion of this problem, consult Legislative Inquiry Into Political Activity: First Amendment Immunity From Committee Interrogation, 65 Yale L. J. 1159 (1956).

${ }^{14}$ See, e.g., Barsky v. United States, 167 F.2d 241, 254 (App. D.C., 1948).

${ }^{15} 197$ F.2d 166 (App. D.C., 1952).

${ }^{16}$ The policy supporting this constitutional doctrine was recognized by Congress in 2 U.S.C. $\$ 193$ (1952), which states that: "No witness is privileged to refuse to testify to any fact, or to produce any paper respecting which he shall be examined by either House of Congress ... or by any committee of either House, upon the ground that his testimony to such fact or his production of such paper may tend to disgrace him or otherwise render him infamous."

${ }^{17} 207$ F.2d 148 (C.A. 3d, 1953).

${ }^{18}$ Ibid., at 158. The court quoted from National Maritime Union of America v. Herzog, 78 F.Supp. 146, 165 (D. D.C., 1948).

I0 Consult Fitz, Criminal Prosecutions for Contempt of Congress, 14 Fed. Bar J. 139 (1954). Watkins v. United States, 77 S.Ct. 1173, 1184 (1957). 
particular question asked the witness fall within the grant of authority actually made by Congress to the committee. ${ }^{20}$

The first requirement, which may be classified as "jurisdictional pertinency," was established by the Supreme Court in a series of cases prior to 1930. The Court in Kilbourn v. Thompson ${ }^{21}$ pointed out that the power of investigation as an implied power was limited in its exercise to enabling Congress to acquire information concerning intended legislation. In view of this limitation, the Court held that the Senate could not compel the attendance of a witness nor delve into his private affairs when it was obvious that Congress had no legislative purpose. However, in McGrain v. Daugherty, ${ }^{22}$ in which an investigation in aid of contemplated legislation was upheld for the first time, the Court stated:

We are bound to presume that the action of the legislative body was with a legitimate object if it is capable of being so construed, and we have no right to assume that the contrary was intended. ${ }^{23}$

Following McGrain subsequent cases have established that when the general subject of the investigation is one concerning which Congress can legislate and where the information sought might aid congressional consideration, the courts will not inquire into congressional motivation. ${ }^{24}$ Notwithstanding the judicial refusal to impugn the motives of Congress, the limitations upon congressional inquiries set forth in Kilbourn represent a constitutional doctrine and, therefore, one which the members of Congress are sworn to uphold.

A related ground of decision in Kilbourn was that the investigatory power does not extend to an area in which Congress is forbidden to legislate. This limitation, like the "legislative purpose" doctrine, logically follows from the premise that the constitutional power to investigate is implied solely to enable Congress to perform its legislative function. The relationship of these limitations to the individual's right to minimal governmental interference was expressed in Sinclair v. United States: ${ }^{25}$

${ }^{20} \mathrm{~A}$ congressional committee does not possess the power to examine private citizens indiscriminately in a mere hope of stumbling upon valuable information. See, e.g., United States v. Orman, 207 F.2d 148 (C.A. 3d, 1953); Bowers v. United States, 202 F.2d 447 (App. D.C., 1953). Likewise, in regard to administrative agencies, the Supreme Court held that a commission's investigative powers could not be used to obtain general information, but only in connection with possible violations of the law. Federal Trade Comm'n v. American Tobacco Co., 264 U.S. 298 (1924).

$$
{ }^{21} 103 \text { U.S. } 168 \text { (1880). } \quad 2273 \text { U.S. } 135 \text { (1927). }
$$

$\approx$ Tbid., at 178. The Court quoted from People v. Keeler, 99 N.Y. 463, 487 (1885).

${ }^{24}$ See, e.g., Watkins v. United States, 77 S.Ct. 1173 (1957) ; Morford v. United States, 176 F.2d 54 (App. D.C., 1949) ; Eisler v. United States, 170 F.2d 273 (App. D.C., 1948) ; United States v. Josephson, 165 F.2d 82 (C.A. 2d, 1947). In accord are the courts' rulings that the motives of the individual members of the committee may not be impugned.

${ }^{25} 279$ U.S. 263 (1929). The Senate in 1924 directed its standing Committee on Public Lands to investigate the disposition of the naval reserves at Teapot Dome by the Interior 
It has always been recognized in this country, and it is well to remember, that few if any of the rights of the people guarded by fundamental law are of greater importance to their happiness and safety than the right to be exempt from all unauthorized, arbitrary or unreasonable inquiries and disclosures. . . . 26

The facts of cases subsequent to Kilbourn have not been deemed to require decision on the ground of jurisdictional pertinency and consequently, although the courts have continued to recognize the doctrine, they have failed to give content to it. ${ }^{27}$ An attempt to provide such content was made by $\mathrm{Mr}$. Justice Douglas in his concurring opinion in Rumely v. United States, ${ }^{28}$ a case in which the petitioner had refused to answer questions relating to the dissemination of his writings. His opinion was based on the premise that

the command that "Congress shall make no law ... . abridging the freedom of speech, or the press" has behind it a long history. It expresses the confidence that the safety of society depends on the tolerance of government for hostile as well as friendly criticism. ... Through the harassment of ... investigations ... government will hold a club over speech and over the press. Congress could not do this by law. ... [and] it may not take the first step in an inquiry ending in fine or imprisonment. ${ }^{29}$

The majority, however, in an opinion by Mr. Justice Frankfurter, accepted the counsel of McGrain and Sinclair to abstain from the adjudication of constitutional questions unless absolutely necessary. ${ }^{30}$ The alternative employed was the use of the limitation that the particular question asked the witness must fall within the grant of authority actually made by Congress to the committee.

The basis of this limitation is found in the wording of the Federal Contempt Statute, which provides penalties for refusal to "answer any question pertinent

and Navy Departments. The Committee called Harry Sinclair to testify concerning various leases to which he was a party, but he refused to answer questions propounded by the Committee on the ground that the whole matter was of exclusively judicial concern and therefore beyond the Senate's legitimate range of inquiry.

${ }^{26}$ Ibid., at 292. But after having announced this limitation, the Court went on to hold that the inquiry involved was within the scope of congressional authority.

${ }^{2}$ See, e.g., United States v. Rumely, 345 U.S. 41 (1953); United States v. Lamont, 236 F.2d 312 (C.A. 2d, 1956); United States v. Orman, 207 F.2d 148 (C.A. 3d, 1953); Bowers v. United States, 202 F.2d 447 (App. D.C., 1953) ; United States v. Kamin, 136 F.Supp. 791 (D. Mass., 1956).

${ }^{2} 345$ U.S. 41 (1953). Rumely was the secretary of an organization known as the Committee for Constitutional Government which, among other things, engaged in the sale of books of a particular tendentiousness. He refused to disclose to the House Select Committee on Lobbying Activities the names of those who made bulk purchases of these books for further distribution and was convicted under the Federal Contempt Statute. The Court of Appeals for the District of Columbia reversed the conviction on the ground that the Committee "had no authority to compel this testimony." 197 F.2d 166, 178 (App. D.C., 1952). The Supreme Court affirmed on other grounds.

${ }^{20}$ Rumely v. United States, 345 U.S. 41, 57, 58 (1953).

${ }^{30}$ Ibid., at 46. 
to the question under inquiry. ..."31 To determine "the question under inquiry" it is necessary to refer to the resolution which authorized the investigation, ${ }^{32}$ for it has been held that the grant of authority is the standard by which the courts will determine whether the question propounded was in fact pertinent. ${ }^{33}$ Since a legislative inquiry anticipates all possible cases which may arise thereunder, pertinency is necessarily broader than relevancy in the law of evidence. A committee's conclusion that corrective legislation should be enacted need not be reached on the basis of relevant evidence alone, for the precision of court procedure is not required. ${ }^{34}$ The concept of pertinency as developed by the courts is more akin to the rule of materiality in the law of evidence. Materiality looks to the relation between the proposition for which the evidence is offered and the issues in the case. As to what is "in issue," the court looks mainly to the pleadings, but there is considerable leeway and the matters in dispute may extend somewhat beyond the issues defined in the pleadings. ${ }^{35}$ So in a contempt proceeding the court in determining pertinency looks to the relation between the question asked and the subject matter of the inquiry. The scope of the inquiry is determined by reference to the au-

\footnotetext{
I1 Consult note 2 supra. It has been contended that the Federal Contempt Statute read together with an authorizing resolution is so vague and indefinite as to deprive a witness of due process of law. Watkins v. United States, 233 F.2d 681 (App. D.C., 1956). But the court in Dennis v. United States, 171 F.2d 986 (App. D.C., 1948), held that Section 192 as applied to the resolution was not unconstitutional as failing to provide an ascertainable standard of guilt.
}

s2 The authority of all investigating committees, except those created for special purposes, is conferred by the Legislative Reorganization Act of 1946, c. 753,60 Stat. 812. For a discussion of the committee organization of the Congress, see Galloway, The Legislative Process in Congress, c. 23 (1953). Each standing committee may, by resolution, authorize an investigation into any subject within its jurisdiction. Where an investigation has been duly authorized, a court may not pass upon the wisdom of Congress in setting up the committee, the private or public character of its members or the propriety of its procedures unless it transgresses authority constitutionally committed to it by Congress. Dennis v. United States, 339 U.S. 162 (1950). A one man subcommittee is a valid subcommittee for the purposes of the Federal Contempt Statute. Emspak v. United States, 349 U.S. 190 (1955).

sa The term "pertinent" as used to describe a requisite for valid congressional inquiry of a witness means pertinent to a subject matter properly under inquiry. United States v. Orman, 207 F.2d 148 (C.A. 3d, 1953). The right of a witness before a congressional committee to refuse to answer a question which is not pertinent is not a personal privilege, such as a right to refrain from self-incrimination, which is waived if not seasonably asserted. Bowers v. United States, 202 F.2d 447 (App. D.C., 1953). Similarly in administrative agency investigations: "The citizen, when interrogated about his private affairs, has a right ... to know why the inquiry is made; and if the purpose disclosed is not a legitimate one, he may not be compelled to answer. . . . The philosophy that constitutional limitations and legal restraints upon official action may be brushed aside upon the plea that good, perchance, may follow, finds no countenance in the American system of government." Jones v. Securities Exchange Comm'n, 298 U.S. 1, 26-27 (1936).

\footnotetext{
* Bowers v. United States, 202 F.2d 447, 448 (App. D.C., 1953).

${ }^{35}$ McCormick, Evidence 314-15 (1954).
} 
thorizing resolution, but because of the relative vagueness of congressional resolutions some leeway is indulged in in determining the scope of the matters defined in the resolution. ${ }^{36}$

It is not sufficient, however, to say that the questions were preliminary in nature and had they been answered would have led to and been followed by questions plainly pertinent. ${ }^{37}$ Under such a theory the pertinency requirement is almost read out of the Contempt Statute. Thus, the government in a contempt proceeding must plead ${ }^{38}$ and prove ${ }^{39}$ the relation of the question, documents sought and the particular witness to the investigation. Although the question of pertinency is properly one of law when it does-not depend upon extrinsic evidence, when evidence aliunde is introduced to prove pertinency the weight and probative value of such evidence is for the jury with authority retained in the court to decide that pertinency has not been established. But if pertinency is deemed proven, the court may so rule and leave

${ }^{36}$ An example of extreme leeway granted by a court to a congressional committee in fixing the bounds of pertinency is illustrated by Townsend v. United States, 95 F.2d 352 (App. D.C., 1938). Townsend appeared before a House committee which was investigating old age pension plans but took offense at the proceedings and walked out of the committee room. He was then charged with contempt and convicted. In its decision upholding this conviction the Court of Appeals said: "A legislative inquiry may be as broad, as searching, and as exhaustive as is necessary to make effective the constitutional powers of Congress. . . . A judicial inquiry relates to a case, and the evidence to be admissible must be measured by the narrow limits of the pleadings. A legislative inquiry anticipates all possible cases which may arise thereunder, and the evidence admissible must be responsive to the scope of the inquiry, which generally is very broad. Many a witness in a judicial inquiry has, no doubt, been embarrassed and irritated by questions which to him seemed incompetent, irrelevent, immaterial and impertinent. But that is not a matter for a witness finally to decide. Because a witness could not understand the purpose of crossexamination, he would not be justified in leaving a court room. The orderly processes of judicial determination does not permit the exercise of such discretion by a witness. The orderly processes of legislative inquiry require that the committee shall determine such questions for itself. Within the realm of legislative discretion, the exercise of good taste and good judgment in the examination of witnesses must be entrusted to those who have been vested with authority to conduct such investigations." Ibid., at 361 .

${ }^{37}$ United States v. Lamont, 236 F.2d 312 (C.A. 2d, 1956) ; Bowers v. United States, 202 F.2d 447 (App. D.C., 1953) ; United States v. Kamin, 136 F.Supp. 791 (D. Mass., 1956).

${ }^{38}$ United States v. Lamont, 236 F.2d 312 (C.A. 2d, 1956). Lamont was called before the Permanent Subcommittee on Investigations of the Senate Committee on Governmental Operations and asked to answer questions relating to his possible participation in or knowledge of subversive or leftist activities. Upon his refusal, the Senate voted to cite Lamont for contempt of Congress and the government obtained an indictment under the Federal Contempt Statute. The District Court dismissed the indictment and the Court of Appeals sustained the dismissal, holding that the government must allege in the indictment the authority of the committee to ask the questions. This ruling enabled the court to dispose of what it considered to be an overly extensive, if not purposeless, invasion of the rights of the individual. This extension of the pertinency limitation enabled the defendant to avoid the expense and humiliation of preparing for trial and defending himself when, as a matter of law, it was clear that the questions propounded were unauthorized.

${ }^{80}$ Bowers v. United States, 202 F.2d 447 (App. D.C., 1953). 
to the jury only the question of whether the defendant refused to answer the question. ${ }^{40}$

In the recent case of Watkins $v$. United States, ${ }^{41}$ the Supreme Court was faced with the problem of how to apply the various limitations on committee investigations discussed in this comment-the validity of the inquiry under the authorizing statute; the constitutional validity of the legislative purpose; and a possible First Amendment privilege. In disposing of the problem, a new, pervasive limitation was invoked. The Court reversed a contempt conviction, based on a refusal to answer committee questions, on the ground that the statutory authorization for the investigation was vague. From this ground several consequences, fatal to the conviction, followed.

First, the Court concluded that it could not make a determination as to whether the questions asked Watkins were pertinent to the statutory purpose of the investigation:

[I]t is impossible . . . to declare that the Committee has ranged beyond the area committed to it by its parent assembly because the boundaries are so nebulous. ${ }^{2}{ }^{2}$

In other words, the delegation of power to the Committee was so lacking in standards that judicial review of the Committee action was impossible. While the Court, in keeping with its prior practice of avoiding constitutional issues in this field, ${ }^{43}$ might have decided the case solely on the basis of inability to review statutory pertinency, the opinion spends only a paragraph on this point. The Court considered that other consequences followed from the vagueness of the authorizing resolution. ${ }^{44}$

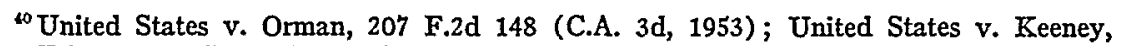
111 F.Supp. 233 (D. D.C., 1953).

${ }^{4} 77$ S.Ct. 1173 (1957). Watkins, an organizer for the United Automobile Workers, refused to answer questions of a subcommittee of the Un-American Activities Committee regarding persons reputed to have been Communists. He admitted knowing some of these persons but refused to answer any questions with respect to certain persons with whom he associated in the past-"I do not believe any law in this country requires me to testify about persons who may in the past have been Communist Party members . . . but who to my best knowledge and belief have long since removed themselves from the Communist moventent." Ibid., at 1176 (italics added). When directed to answer the question Watkins refused and his indictment for contempt followed. He was found guilty in the District Court and sentenced according to the provisions of the Federal Contempt Statute. The Court of Appeals reversed the conviction and held that the questions put to Watkins could only be asked in pursuit of a valid legislative purpose; that is, with a view to proposing remedial legislation. Due to the highly controversial nature of the issues raised, the Court of Appeals agreed to rehear the arguments en banc, and upon such hearing reversed the decision of the three judge court and reinstated the conviction. Watkins v. United States, 233 F.2d 681 (App. D.C., 1956).

"Watkins v. United States, 77 S.Ct. 1173, 1188 (1957).

${ }^{43}$ For a general discussion of the cases, consult Hitz, Criminal Prosecution for Contempt of Congress, 14 Fed. Bar J. 139 (1954).

"A consequence of vagueness not dealt with by the Court is the preclusion of review of jurisdictional pertinency: the legitimacy of the legislature's purpose in authorizing an investigation can hardly be determined when it is not known what that purpose is. 
The Court held that Watkins had been denied due process because, at the time the questions were asked, he could not have reasonably known whether they were "pertinent to the question under inquiry" within the meaning of the Criminal Contempt Statute. ${ }^{45}$ The Court's reasoning on this point is not altogether clear. At one point the Court says that due process would have been satisfied had the Committee explained clearly to Watkins the purpose of the inquiry. ${ }^{40}$ This implies that for due process purposes the Committee itself could define this purpose, that precise definition by the authorizing resolution was not necessary. However, the Court, having determined that the opening statement of the Committee Chairman "was woefully inadequate to convey sufficient information as to the pertinency of the questions to the subject under inquiry," went on to hold that

Petitioner was thus not accorded a fair opportunity to determine whether he was within his rights in refusing to answer, and his conviction is necessarily invalid under the Due Process Clause. ... .47

It would seem that Watkins, in order to determine whether he could lawfully refuse to answer, would have to know whether the questions had statutory and jurisdictional pertinency. While a precise statement by the Committee Chairman might have given Watkins advice on this point, it would seem that the ultimate determination could only be made by reference to the authorizing resolution. Thus the vagueness of this statutory authorization appears crucial to the due process objection, and the due process holding in Watkins cannot be avoided by simply a careful explanation to each witness of the purpose of the investigation. If grants of authority to congressional committees must meet the vagueness requirements imposed on criminal statutes, the congressional practice of establishing standing committees with roving commissions to investigate would seem to have been called into serious question. ${ }^{48}$

Another of the Court's reasons for holding the vagueness of the statutory authorization to be fatal to Watkins' conviction was that this vagueness prevented a determination of whether a First Amendment privilege had been violated. ${ }^{49}$ According to the Court, this vagueness, by preventing ascertainment of the legislative purpose, precluded a determination of whether the infringement of free speech caused by the Committee investigation was justified by a clear legislative need.

The section of the Court's opinion dealing with the free speech question is puzzling. On the one hand, the Court seems to have established that the First Amendment can create a privilege not to answer a committee question; were

${ }^{45}$ Watkins v. United States, 77 S.Ct. 1173, 1193 (1957).

${ }^{46}$ Ibid., at 1190-93.

${ }^{2 s}$ Consult The Power of Congress To Investigate and To Compel Testimony, 70 Harv.

L. Rev. 671, 680-81 (1957).

${ }^{\iota 0}$ Watkins v. United States, 77 S.Ct. 1173, 1184-85, 1188-89 (1957). 
there no First Amendment right to remain silent, the Court would not have had to know the legislative need for the investigation in order to determine whether there had been a First Amendment violation. On the other hand, if a First Amendment right were really involved, it would seem that few legislative needs would justify investigations infringing this right, and the present Court seems unlikely to find such a need in regard to legislation concerning subversion. Perhaps the Court in Watkins wished to avoid the problem of balancing the basic conflict between a right to privacy of belief and the legislative need for information. However, the Court's holding that the First Amendment is applicable requires that eventually this problem be faced, and indicates that, even where a committee with a valid legislative purpose asks questions clearly pertinent to a precise authorizing resolution, there may still be First Amendment limitations on questions concerning the witness's political associations and beliefs.

\section{THE RIGHT OF PEREMPTORY CHALLENGE}

Every American jurisdiction provides by statute ${ }^{1}$ that parties to a civil or criminal proceeding are entitled to reject a certain number of prospective jurors $^{2}$ without assigning cause. Through the exercise of this right to peremp-

1 "In civil cases, each party shall be entitled to three peremptory challenges. Several defendants or several plaintiffs shall be considered as a single party for the purposes of making challenges." 62 Stat. 953 (1948), 28 U.S.C.A. $\$ 1870$ (1948). "If the offense charged is punishable by death, each side is entitled to 20 peremptory challenges. If the offense charged is punishable by imprisonment for more than one year, the government is entitled to 6 peremptory challenges and the defendant or defendants jointly to 10 peremptory challenges. If the offense charged is punishable by imprisonment for not more than one year or by fine or both, each side is entitled to 3 peremptory challenges." Fed. Rules Crim. Proc. 24(b).

No constitutional basis is recognized for the right of peremptory challenge. "[I]n criminal cases; trial by an impartial jury is all that is secured." Stilson v. United States, 250 U.S. 583, 586 (1919). There is even less constitutional support for peremptory challenges in civil cases, since an impartial jury is not guaranteed, as it is in criminal cases by the Sixth Amendment. The Seventh Amendment reads: "In suits at common law ... the right of trial by jury shall be preserved."

This apparently more solicitous attitude toward a criminal defendant is reflected by the fact that in federal courts and in all states, with one or two possible exceptions, more peremptory challenges are allowed in criminal cases than are allowed in civil cases. One exception is Vermont, which allows the same number of challenges in any proceeding in any court. Vt. Rev. Stat. (1947) \$1726.

For examples of state peremptory challenge statutes, consult Cal. Code Civ. Proc. (Deering, 1953) $\$ 601$, Cal. Penal Code (Deering, 1949) $\$ \$ 1070,1070.5 ;$ Ill. Rev. Stat. (1955) c. $110, \S 66$, c. $38, \$ 742$; N.Y. Civ. Prac. Act (1920, as amended to 1956) $\$ 451$, N.Y. Crim. Code (1881, as amended to 1953 ) $\$ 373$. Rhode Island is exceptional in not allowing peremptory challenges in criminal proceedings in which the defendant is charged with treason, murder, robbery, rape, arson, or burglary. R.I. Laws (1938) c. $625 \$ \$ 17,67$. That state does allow peremptory challenges in civil cases and other criminal cases, however. R.I. Laws (1938) c. 507, \$2.

"Hereafter, the word "veniremen" is often used instead of "prospective jurors." 